\title{
Influences on the fraction of hydrophobic and hydrophilic black carbon in the atmosphere
}

\author{
G. R. McMeeking ${ }^{1}$, N. Good ${ }^{1}$, M. D. Petters ${ }^{2}$, G. McFiggans ${ }^{1}$, and H. Coe ${ }^{1}$ \\ ${ }^{1}$ Centre for Atmospheric Science, University of Manchester, Manchester, UK \\ ${ }^{2}$ Department of Marine Earth and Atmospheric Sciences, Raleigh, NC, USA
}

Received: 8 December 2010 - Published in Atmos. Chem. Phys. Discuss.: 13 January 2011

Revised: 4 April 2011 - Accepted: 20 May 2011 - Published: 31 May 2011

\begin{abstract}
Black carbon (BC) is a short term climate forcer that directly warms the atmosphere, slows convection, and hinders quantification of the effect of greenhouse gases on climate change. The atmospheric lifetime of BC particles with respect to nucleation scavenging in clouds is controlled by their ability to serve as cloud condensation nuclei (CCN). To serve as CCN under typical conditions, hydrophobic BC particles must acquire hygroscopic coatings. However, the quantitative relationship between coatings and hygroscopic properties for ambient $\mathrm{BC}$ particles is not known nor is the time scale for hydrophobic-to-hydrophilic conversion. Here we introduce a method for measuring the hygroscopicity of externally and internally mixed $\mathrm{BC}$ particles by coupling a single particle soot photometer with a humidified tandem differential mobility analyzer. We test this technique using uncoated and coated laboratory generated model BC compounds and apply it to characterize the hygroscopicity distribution of ambient BC particles. From these data we derive that the observed number fraction of $\mathrm{BC}$ that is $\mathrm{CCN}$ active at $0.2 \%$ supersaturation is generally low in an urban area near sources and that it varies with the trajectory of the airmass. We anticipate that our method can be combined with measures of air parcel physical and photochemical age to provide the first quantitative estimates for characterizing hydrophobic-to-hydrophilic conversion rates in the atmosphere.
\end{abstract}

\section{Introduction}

Black carbon (BC) particles absorb solar radiation, leading to heating and suppression of convection in the atmosphere. Black carbon has an average lifetime of $1 \pm 1$ weeks (Rodhe

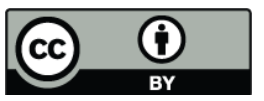

Correspondence to: M. D. Petters

(markus_petters@ncsu.edu) et al., 1972) and contributed $\sim 0.9 \mathrm{~W} \mathrm{~m}^{-2}$ to the top of atmosphere forcing during 2005 (Ramanathan and Carmichael, 2008). Forcing estimates such as these rely on up-to-date emission inventories and accurate description of the wet removal process. Freshly emitted BC particles are hydrophobic and generally not able to serve as cloud condensation nuclei (CCN) at atmospherically relevant critical supersaturations (Lammel and Novakov, 1995; Dusek et al., 2006; Koehler et al., 2009). Over time BC particles acquire hygroscopic material that lowers the critical supersaturation $(s)$ at which $\mathrm{BC}$ particles can undergo nucleation scavenging (Wyslouzil et al., 1994; Weingartner et al., 1997; Zhang et al., 2008). Hygroscopic material can be acquired by multiple processes, including condensation of secondary products such as sulfates and organics or coagulation with hygroscopic particles or cloud drops. We will refer to internally mixed BC particles as "coated", where it is understood that no specific process is implied. Some global models (Cooke and Wilson, 1996; Koch, 2001; Chung and Seinfeld, 2002; Koch et al., 2009) parameterize the hydrophobic-to-hydrophilic conversion as an exponential turnover with an e-folding time $(\tau)$ of $24-39 \mathrm{~h}$ (e.g., Kanakidou et al., 2005; Koch et al., 2009), while others directly simulate the coagulation and condensation processes that cause the conversion (e.g., Jacobson, 2010). The time scale appears to be controlled by BC interaction with more hydrophilic species such as sulfates, nitrates, and secondary organic aerosol via condensation and/or coagulation (Petters et al., 2006; Riemer et al., 2010). Detailed microphysical models predicting $\tau$ indicate that the time scale varies between day and night, and that aging proceeds rapidly during daytime (Riemer et al., 2010). Verifying these differences experimentally is important because hydrophobic-tohydrophilic conversion time scales represent a major uncertainty in determining $\mathrm{BC}$ lifetime and predicting its distribution throughout the atmosphere.

The recent development of the single particle soot photometer (SP2) (Stephens et al., 2003; Baumgardner et al.,

Published by Copernicus Publications on behalf of the European Geosciences Union. 
2004; Schwarz et al., 2006) has allowed characterization of the refractory $\mathrm{BC}(\mathrm{rBC})$ mass distribution and mixing state in great detail. Briefly, the SP2 exposes individual particles to a $1064 \mathrm{~nm}$ laser beam. Particles that absorb light sufficiently at this wavelength are heated to their incandescence temperature and the emitted thermal radiation is measured by optical detectors and converted to mass. The instrument also measures light scattered by particles to determine coating and mixing state information for rBC. Combined, the system quantifies the refractory mass of the absorbing particle, provides coating information and resolves the $\mathrm{rBC}$ mixing state for an ensemble of particles.

The relationship between hygroscopic growth and coating material/thickness has been studied for laboratory generated BC particles (Wyslouzil et al., 1994; Weingartner et al., 1997; Gysel et al., 2003; Popovicheva et al., 2008a; Zhang et al., 2008). These studies show that water uptake is controlled by the amount of coating material and that agglomerated particles may restructure from a combination of water soluble coating and absorbed water. Several recent studies also investigated the CCN activity of various model soot particles (Lammel and Novakov, 1995; Dusek et al., 2006; Koehler et al., 2009; Snider et al., 2010), showing that untreated (i.e. uncoated) BC activates at sizes and supersaturations larger than those predicted by the Kelvin equation, effectively rendering most of these particles $\mathrm{CCN}$ inactive under atmospherically relevant conditions. The water uptake studies and CCN studies are related through theoretical descriptions that quantitatively link hygroscopic growth and CCN activity. Water adsorption may lead to the nucleation of cloud droplets in various ways for uncoated soot (Fletcher, 1958; Mahata and Alofs, 1975; Henson, 2007; Sorjamaa and Laaksonen, 2007; Popovicheva et al., 2008b), while modified Köhler theory that accounts for the insoluble core describes coated soot (see Junge, 1950; Pruppacher and Klett, 1997; Weingartner et al., 1997; Snider et al., 2003; Petters and Kreidenweis, 2007, 2008 for theoretical discussion and; Henning et al., 2010 for experimental verification). These studies addressed the relationship between water uptake and $\mathrm{CCN}$ properties for laboratory generated model soot aerosol. The link has not yet been established for externally mixed ambient aerosol because water uptake measurements are generally not sensitive to specific particle types such as BC and most previous measurements of $\mathrm{BC}$ mixing state do not directly measure hygroscopic properties. Investigations using either the SP2 or single particle mass spectrometry have examined the relative abundance of externally and internally mixed $\mathrm{BC}$ particles and the timescales required for $\mathrm{BC}$ to become well mixed with other species (e.g., Moteki et al., 2007; Schwarz et al., 2008; Moffet and Prather, 2009; Pratt and Prather, 2010), but not directly measured the relationship between $\mathrm{BC}$ mixing processes and hygroscopicity.

We address this gap by proposing a new method that combines the SP2 with the humidified tandem differential mobility analyzer (HTDMA) technique (Rader and McMurry,
1986). Our approach is similar to those employed by Herich et al. (2008) and Zelenyuk et al. (2008), who used single particle mass spectrometers downstream of HTDMAs to probe particle composition as a function of hygroscopicity. The HTDMA measures the wet size distribution by first selecting a nominal particle diameter based on electrical mobility, exposing the particles to a specified relative humidity, and then measuring the resulting wet size distribution using a condensation particle counter (CPC). The addition of the SP2 identifies $\mathrm{rBC}$ in the output of the humidified differential mobility analyser (DMA). The water uptake properties of BC particles can also be linked directly to the thickness of the coating measured by the SP2. Combined with Köhler theory this provides direct insights into the relationship between rBC size, mixing state, and the ability of the particles to undergo nucleation scavenging in clouds. The purpose of this work is to describe the HTDMA-SP2 setup, present tests with laboratory generated pure and mixed model $\mathrm{BC}$ particles, explain the data processing procedures, report on initial ambient data collected in a major urban center (central Manchester in the United Kingdom), and discuss how data products from this technique can be used in future targeted campaigns to improve our understanding of $\mathrm{rBC}$ aging processes.

\section{Methods}

Model black carbon particles were generated by atomizing solutions of black carbon proxies suspended in ultrapure deionized water. The aerosol was diluted with particlefree air and dried prior to sampling by the HTDMA-SP2 instrument. Black carbon proxies included glassy carbon, aquadag and carbon black. Glassy carbon particles consist of monomers or aggregates of spherical non-graphitic carbon particles while aquadag consists of clumps of non-spherical graphite sheets (Moteki et al., 2010). The morphology and structure of carbon black particles is unknown. To generate coatings, ammonium sulfate or malonic acid was added to the BC suspensions. Since the shape of our particles was unknown, the relationship between mobility diameter and mass (effective density) was not clearly defined and consequently we refer to the diameter of particles classified by a DMA as mobility diameter $\left(D_{\mathrm{mob}}\right)$. Uncertainties introduced by this limitation are discussed later.

Ambient data were collected at the University of Manchester between 3 and 16 August 2010. Manchester is located at the center of the British Isles and prevailing winds are southerly/westerly resulting in a maritime climate. Manchester is situated on the urban east-west corridor that connects Leeds and Liverpool, so incoming air may have already acquired some BC. Aerosol was sampled through $3 / 8^{\prime \prime}$ copper tubing running from the instrument laboratory to the outside through a port in the window $\sim 20 \mathrm{~m}$ a.g.l. The laboratory is located $\sim 100 \mathrm{~m}$ from a major urban corridor (with a scheduled passenger bus frequency of one per minute during 
daytime) and around $2 \mathrm{~km}$ south of the Manchester city center. We therefore expect to have sampled a mixture of $\mathrm{BC}$ from local as well as regional sources.

\subsection{The single particle soot photometer (SP2)}

The SP2 instrument used in this study and the data processing and analysis procedures used to interpret the instrument output are described elsewhere (McMeeking et al., 2010). Briefly, the SP2 uses the maximum detected emission of thermal radiation ("incandescence") to determine the $\mathrm{rBC}$ mass for individual $\mathrm{rBC}$-containing particles. Moteki and Kondo (2010) showed that the response of the SP2 depends, in part, on the refractive index and shape of the particle, so the choice of calibration material is critical to accurately determine $\mathrm{rBC}$ mass $\left(m_{\mathrm{BC}}\right)$. We calibrated the instrument using mobility-selected (TSI 3085) glassy carbon spheres with density $=1.42 \mathrm{~g} \mathrm{~cm}^{-3}$ (Liu et al., 2010) and $\left|\left(m^{2}-1\right) /\left(m^{2}+2\right)\right|=0.81$, where $m$ is the complex refractive index (Moteki et al., 2010). The nominal detection range of the SP2 is between approximately $m_{\mathrm{BC}}=0.5-300 \mathrm{fg}$, although the lower detection range depends on the intensity of the intra-cavity laser (Schwarz et al., 2010). In this study we only sampled $D_{\mathrm{mob}}=147,193$ and $286 \mathrm{~nm}$, which are sufficiently massive to ignore any laser-power related detection limitations. Particles containing only small amounts of $\mathrm{rBC}$ relative to other material may not be detected.

The SP2 has two avalanche photodiodes (APDs) that measure incident light $(\lambda=1064 \mathrm{~nm})$ scattered by particles crossing the Gaussian profile cavity laser. One detector is a modified four-element APD that allows the Gaussian scattering function to be constructed from the leading edge of the regular APD signal prior to its distortion by any laser-induced heating (Gao et al., 2007). Non-absorbing particles can be sized simply from the peak of the unperturbed Gaussian profile scattering signal. The scattering response of the regular APD was calibrated with polystyrene latex spheres (PSL) over a range of sizes with refractive index $n=1.58$.

\subsection{The HTDMA-SP2 setup}

The HTDMA used in this study is described in detail elsewhere (Cubison et al., 2005, Good et al., 2010). Briefly, particles were dried to $\sim 20 \% \mathrm{RH}$ inside a desiccant drier, charge equilibrated inside a ${ }^{90} \mathrm{Sr}$ neutralizer, size selected inside a DMA, and humidified to $\mathrm{RH}=90 \%$. The resulting humidified size distribution was scanned using a second DMA connected to a water based condensation particle counter (water-CPC, TSI 3782). The DMAs were operated with recirculating sheath flows and a sheath-to-sample flow rate of 10:1. A detailed flow schematic is presented in Fig. 1. The SP2 was used, in addition to the CPC, to measure the humidified size distribution of rBC-containing particles. We inverted the SP2 counts using the same method that is traditionally used to process CPC counts sampled by the humidi- fied DMA of the setup. The traditional inversion is described in detail by Gysel et al. (2009).

Each particle detected by the SP2 was categorized and quantified according to the following scheme:

i. Purely scattering particles: If a particle was detected by the APD sensor but no thermal radiation was observed, the mass of $\mathrm{rBC}$ in the particle was either below the SP2 incandescence detection limit or the particle did not contain $\mathrm{rBC}$. These particles were classified as purely scattering and assigned a size using the intensity of the APD detector signal and the PSL calibration response.

ii. rBC mass: Particles with detectable incandescence signal were classified as $\mathrm{rBC}$ particles and assigned an $\mathrm{rBC}$ mass $\left(m_{\mathrm{BC}}\right)$ based on the calibration between incandescence signal and mass obtained from laboratory generated glassy carbon.

iii. Coating thickness: Coating thickness was estimated by comparing $m_{\mathrm{BC}}$ with other measures of unperturbed particle size, including mobility diameter from the DMA and optical diameter from the SP2. Both estimates are susceptible to measurement artifacts that will be discussed when we present the data.

iv. Thickly coated particles: The time required for the particle to reach its peak thermal emission was estimated from the time between peak scattering and thermal radiation signals or time delay (Shiraiwa et al., 2007). Particles having time delays longer than a critical time delay $\left(t_{\mathrm{d}}>1 \mu \mathrm{s}\right)$ were classified as thickly coated. The critical time delay was instrument setup dependent and was chosen based on the location of the minimum of the histogram of the time-delay response (see Fig. 2 in Shiraiwa et al., 2007).

\subsection{The hygroscopicity framework and its relationship to aging}

To analyze the growth factor data in terms of aging, the data were converted into an equivalent hygroscopicity parameter, $\kappa$, (Petters and Kreidenweis, 2007) using:

$\kappa=\frac{\left(g f^{3}-1\right)\left(1-a_{\mathrm{w}}\right)}{a_{\mathrm{w}}}$

$a_{\mathrm{w}}=\frac{\mathrm{RH}}{\exp \left(\frac{A}{g f D_{\mathrm{d}}}\right)}$

where, $g f=D / D_{\mathrm{d}}$ is the diameter growth factor, $D$ is the diameter, $D_{\mathrm{d}}$ is the dry diameter, $a_{\mathrm{w}}$ is the water activity, $\mathrm{RH}$ is the fractional relative humidity, $A=8.69 \times 10^{-6} \sigma / T, T$ $[\mathrm{K}]$ is temperature, and $\sigma\left[\mathrm{J} \mathrm{m}^{-2}\right]$ is the surface tension of the aqueous solution/air interface. Here, $\sigma=0.072 \mathrm{~J} \mathrm{~m}^{-2}$ and $T=298.15 \mathrm{~K}$ are chosen as reference state. Physically, $\kappa$ represents the amount of water associated per unit dry volume normalized by relative humidity. 


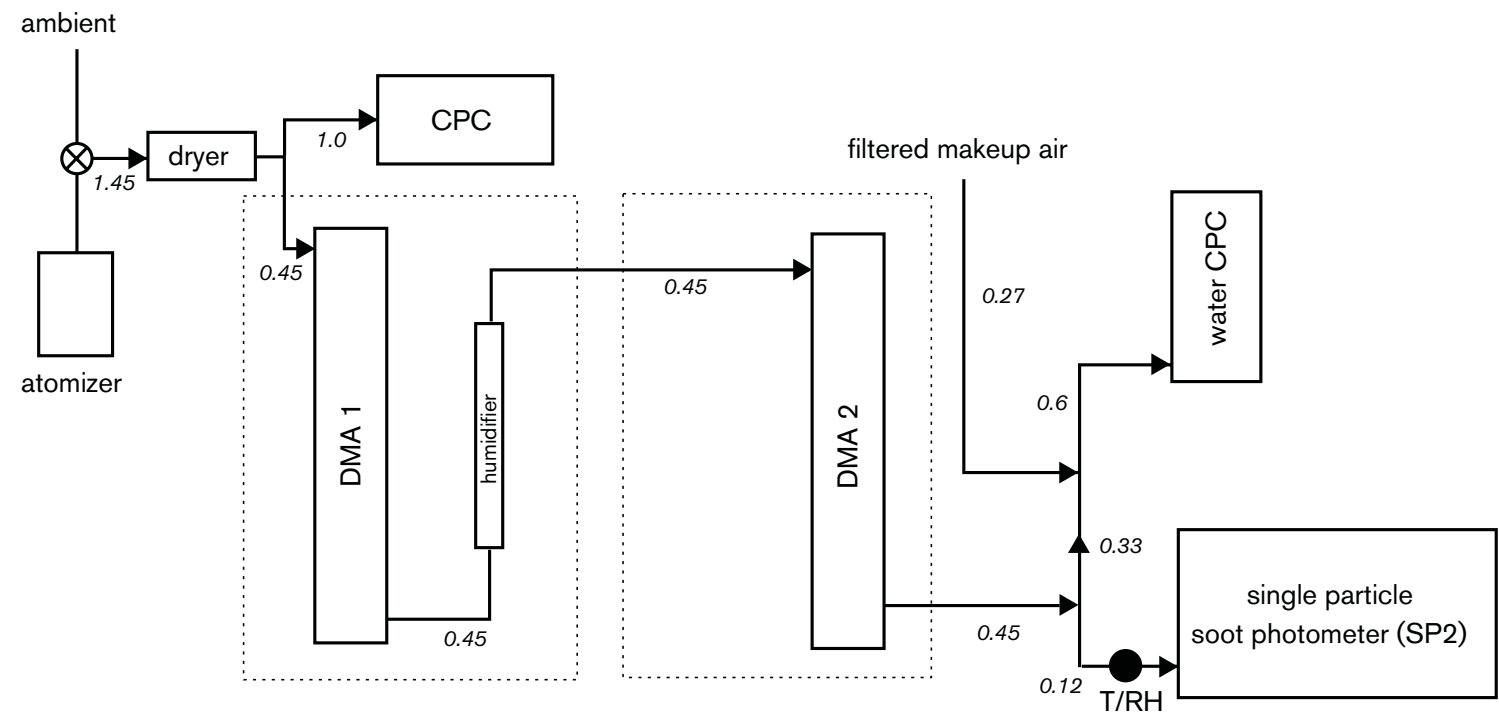

Fig. 1. Schematic of the instrument setup.

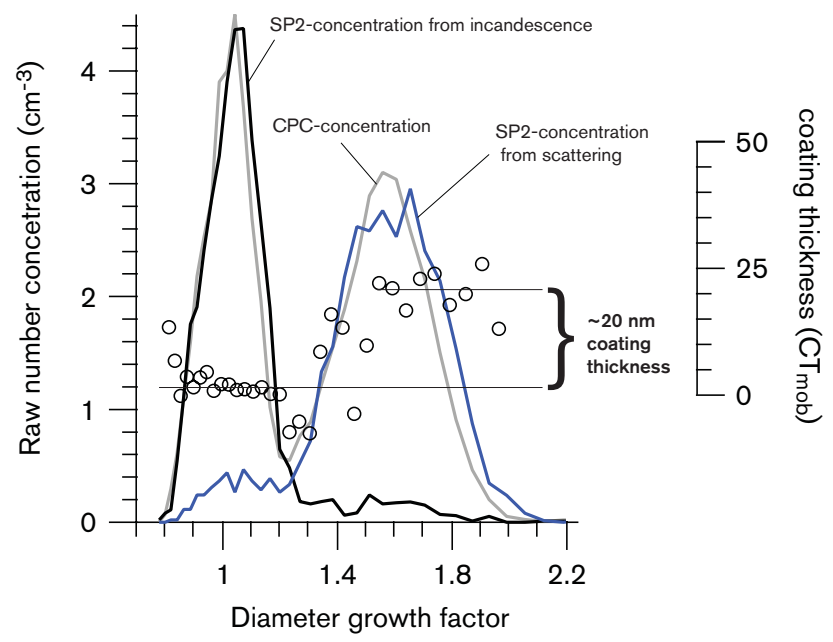

Fig. 2. Concentrations of total particles measured by the CPC, rBC and purely scattering particles measured by the SP2 and the mean mobility-derived coating thickness determined from SP2 mass measurements plotted as a function of growth factor.

For idealized multicomponent particles, e.g., a spherical $\mathrm{rBC}$ core with an ammonium sulfate coating, the overall $\kappa$ of the particle can be computed using the following mixing rule $\kappa=\sum \epsilon_{i} \kappa_{i}$

where $\epsilon_{i}$ is the volume fraction and $\kappa_{i}$ is the hygroscopicity parameter of the $i$-th component in the particle. For a nonhygroscopic and insoluble compound $\kappa=0$. Equation (2) predicts that for a coating with a constant effective $\kappa$, coating thickness and observed overall $\kappa$, or growth factor, form a unique relationship that can be retrieved directly from the HTDMA-SP2 data.
Models consider a BC particle to be "aged" if it has acquired sufficient coating material to serve as a CCN. Conceptually it is helpful to choose a typical maximum supersaturation for different cloud types, e.g., $s=0.2 \%$ for stratus clouds and $s=1 \%$ for cumulus clouds. The question of whether a particle is aged or not can then be addressed by computing the critical supersaturation of each particle and determining whether these threshold values are met. In practice, the critical supersaturation required for the particle to serve as $\mathrm{CCN}$ can be estimated from the measured dry size and overall $\kappa$ by finding the maximum of Eq. (6) in Petters and Kreidenweis (2007). Thus BC aging can be understood in terms of coating thickness if the effective $\kappa$ of the coating material is known. In fact, the coating thickness can be calculated from the measured $\kappa$ distribution under these assumptions. BC emitted with a coating or other hygroscopic inclusion will be considered aged by this definition. In practice, the number fraction of aged particles is computed by assigning a threshold growth factor for each dry size above which the particle is $\mathrm{CCN}$ active. The relative number fraction of aged particles is then computed by integrating the growth factor distribution above the threshold value and dividing by the total $\mathrm{rBC}$ number concentration detected during the scan. This procedure rests on the assumption that growth factor-derived $\kappa$ values can be reliably extrapolated to supersaturated conditions. If sparingly soluble compounds are present they will not contribute to the measured $\kappa$ (Petters and Kreidenweis, 2008) and the fraction $F_{\text {aged }}$ will be underestimated. 


\section{Results}

Example raw $g f$ scans with minimal processing applied are shown in Figs. 2 and 3. These figures correspond to a single scan over the humidified size distribution. Scan times depended on observed particle concentrations, but they were typically between 10 and 30 min. Figure 2 shows an example for ambient aerosol and contrasts a typical growth factor distribution measured by the CPC with the SP2-derived distributions for scattering and $\mathrm{rBC}$-containing particles. The coating thickness derived from $m_{\mathrm{BC}}$ of the rBC cores and the dry $D_{\text {mob }}$ as a function of $g f$ is superimposed. The calculations for coating thickness were restricted to the singlycharged particle mode, which was identified from the mass distributions measured by the SP2. Coating thickness is seen to increase with increasing growth factors. Uncertainties in this coating parameter from particle shape make the absolute value of the coating thickness uncertain and this will be quantified in Sect. 4.1.

\subsection{Pure rBC proxy materials}

We characterized the HTDMA-SP2 system using three different $\mathrm{rBC}$ proxy materials (glassy carbon spheres, aquadag and carbon black) that have been used previously to evaluate SP2 measurements (Moteki et al., 2010; Schwarz et al., 2010). All three rBC proxy samples had a dominant nonhygroscopic mode that was centered at $g f \sim 1.0$ (Fig. 3a-c). The combination of $\mathrm{rBC}$ and non-rBC particles detected by the SP2 was in agreement with CPC measurements for all scans. The $g f=1$ mode was dominated by $\mathrm{rBC}$ particles for all three proxy materials.

\subsection{Mixtures of rBC proxies, ammonium sulfate and malonic acid}

To test the ability to detect coatings and mixing state we atomized mixtures of the carbon black $\mathrm{rBC}$ proxy particles and ammonium sulfate or malonic acid. Examples of two HTDMA-SP2 scans for the mixtures of carbon black with ammonium sulfate and carbon black mixed with malonic acid are shown in Fig. 3d and e, respectively. The hygroscopic mode dominated the non-hygroscopic mode for both cases, but the non-hygroscopic mode could still be observed, centered at $g f=1.0$. The non-hygroscopic mode was dominated by $\mathrm{rBC}$ particles and the hygroscopic mode dominated by non-BC (purely scattering) particles. The sum of SP2measured $\mathrm{rBC}$ and purely scattering particles was in agreement with the CPC concentrations. The $g$ f's measured for the hygroscopic modes (1.75 and 1.6) were consistent with what we expected for pure, $193 \mathrm{~nm}$ diameter ammonium sulfate $(g f=1.76)$ and malonic acid $(g f=1.67)$ particles at $\mathrm{RH}=90 \%$. Unlike the "pure" rBC proxy compounds shown in Fig. 3a-c, the mixture cases featured a small concentration of $\mathrm{rBC}$-containing particles detected as a tail extending into the hygroscopic mode. We believe that these particles were coated with either ammonium sulfate or malonic acid.

\subsection{Manchester ambient sampling}

Two ambient $g f$ scans are shown in Fig. $3 \mathrm{f}$ and g. These scans exhibited a non-hygroscopic mode centered at $g f=1.0$ and a hygroscopic mode centered at $g f=\sim 1.5$. The population of particles that did not take up water as dominated by $\mathrm{rBC}$ with an $\sim 10 \%$ contribution by number of non-rBC particles. The results differ from our observations during the mixture and single component tests and indicated the presence of additional non-hygroscopic particles that do not contain $\mathrm{rBC}$. The hygroscopic mode was dominated by purely scattering or non-rBC containing particles, however the 16 August measurements (Fig. $3 \mathrm{~g}$ ) showed an appreciable increase of rBC particles in the hygroscopic mode, similar to the mixed test case results, but even more pronounced.

Figure 4 shows aerosol hygroscopicity measured by the HTDMA-SP2 system during the entire ambient sampling period between 5 and 16 August 2010. Contrary to the data in Fig. 2, these data were inverted as described in the methods section. We converted measured $g f$ into $\kappa$ and separated the measurements of $\mathrm{rBC}$-containing particles, purely scattering particles, and total particles identified by the SP2 (that were also in agreement with CPC results). The total particle results showed the near-continuous presence of non-hygroscopic and hygroscopic modes centered at $\kappa=0$ and 0.4. rBC-containing particles were found mostly in the non-hygroscopic mode, though we did observe periodic increases in hygroscopic rBC concentrations (e.g., 14-16 August). Purely scattering particles were primarily in the hygroscopic mode, but there was always a small contribution to the non-hygroscopic mode that for isolated periods became stronger. Overall concentrations fluctuated, reflecting changes in transport and local conditions.

We examined the meteorological conditions during the measurement period to provide a context for interpreting the HTDMA-SP2 ambient sampling results. Meteorological conditions during the ambient measurement period were unsettled, with frontal systems passing over the UK on the 3, 6, 9, and 12 August. As a result, Manchester experienced several days of cloudy, wet and windy weather. Ceilometer measurements taken from the roof of an adjacent university building indicated the nearly continuous presence of low-clouds (cloud deck beginning at 500-1500 $\mathrm{m}$ above the surface) between 6 and 14 August and several intermittent rain events. The pattern broke at roughly 12:00 UTC $14 \mathrm{Au}-$ gust when a high-pressure ridge moved over the UK from the west, resulting in clear skies over Manchester.

Modeled backward trajectories, terminating at $500 \mathrm{~m}$ a.g.l. over the Manchester grid box, reflected the larger-scale flow. Several examples at selected times of interest are shown in 

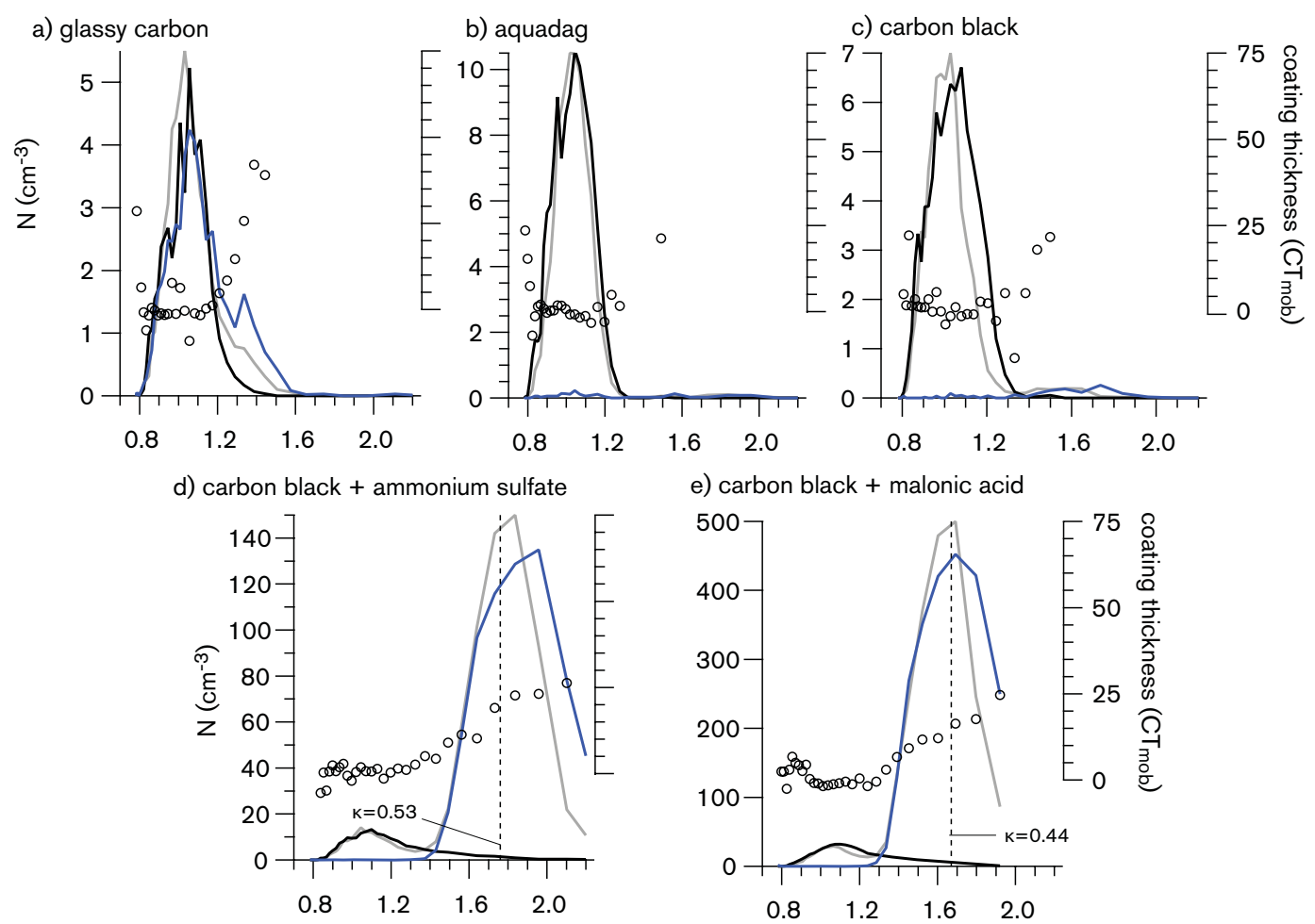

f) Manchester, 4 Aug 0600 BST

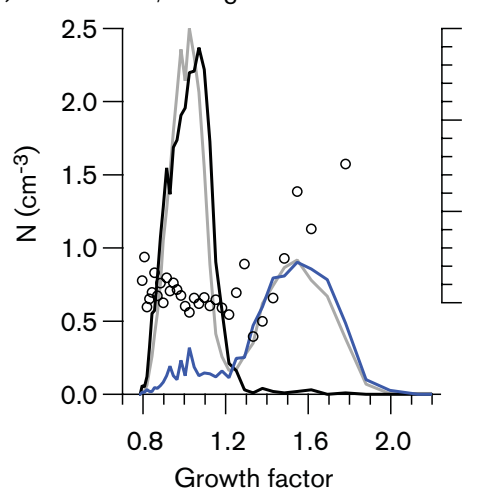

g) Manchester, 16 Aug 0700 BST

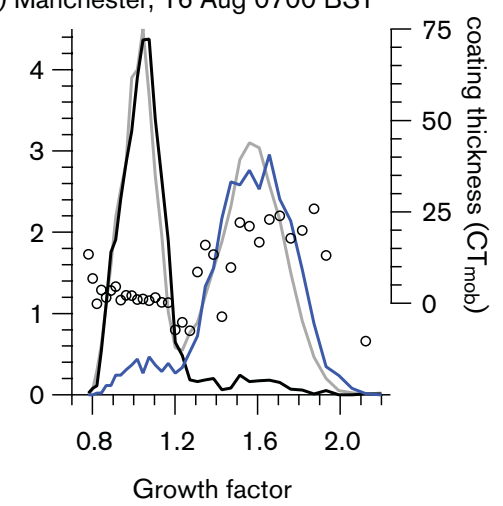

Fig. 3. Same as Fig. 2 but for different BC particle types and mixtures. All rBC mean diameter calculations assumed an $\mathrm{rBC}$ density of 1.42, equal to that of the glassy carbon calibration particles. rBC species shown are (a) glassy carbon spheres, (b) aquadag, (c) carbon black, (d) mixture of ammonium sulfate and carbon black, (e) mixture of malonic acid and carbon black, and (f) and (g) show two example scans measured for ambient Manchester air outside the laboratory for the mornings of 4 and 16 August 2010. Dashed vertical lines give expected growth factors for pure ammonium sulfate and malonic acid.

Fig. 5. The two backward trajectories arriving on 3 and 7 August show typical flow patterns during the early portion of ambient measurements that featured frequent frontal passages and westerly flow. The flow pattern changes around 14 August when flow over the northern UK was influenced by the high pressure system and became easterly, as shown by the trajectories for 14 and 16 August. The backward trajectory for 12:00 UTC on 8 August shows a stronger northerly component compared to other trajectories during the westerly period.
Gridded carbon monoxide (CO) emissions from the UK National Atmospheric Emissions Inventory for 2008 are also shown in Fig. 5. Carbon monoxide and rBC are strongly correlated because both are emitted by incomplete combustion and previous SP2 measurements have shown strong $\mathrm{rBC}$ correlations with CO over the UK (McMeeking et al., 2010). In addition to Manchester itself, the largest $\mathrm{CO}$ (and rBC) emissions near Manchester are found in the Liverpool region to the west, the Leeds/Sheffield region to the east and the Birmingham and London urban areas to the south. The trajectories shown in Fig. 5 reaching Manchester from the west 


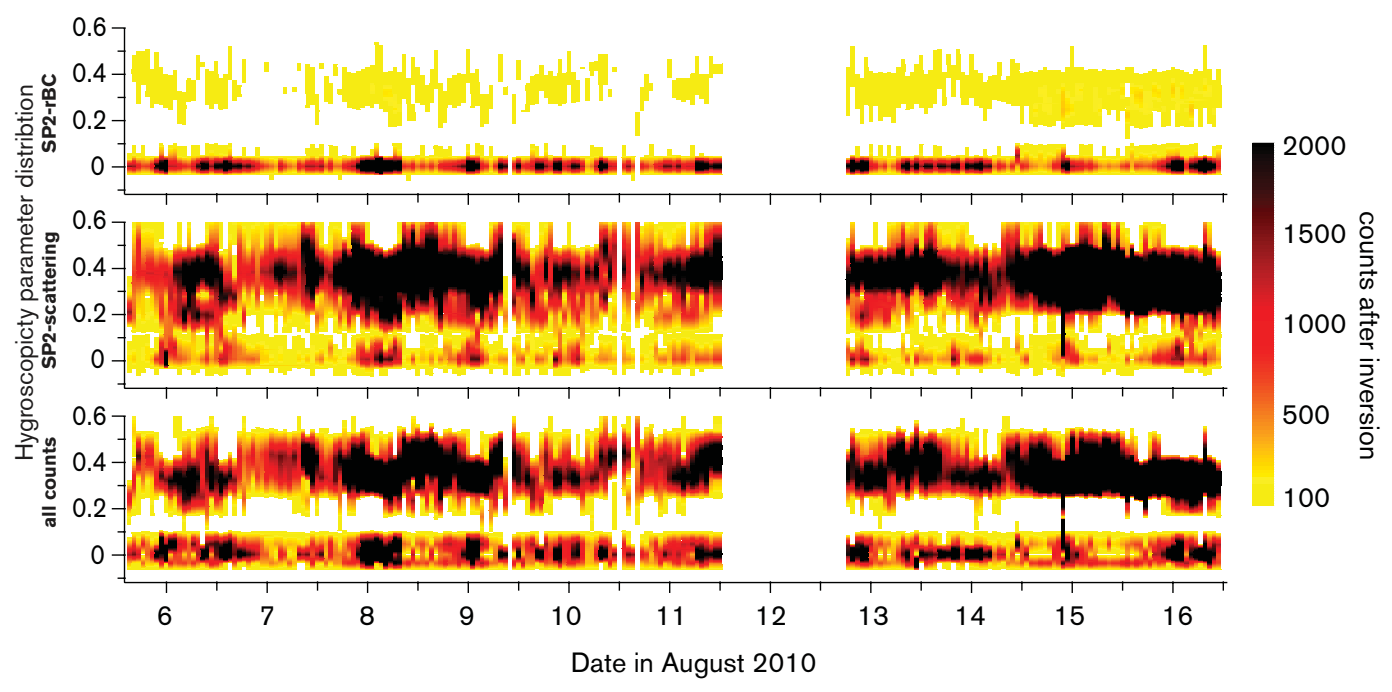

Fig. 4. Hygroscopicity parameters for mixed particle mobility dry diameter $193 \mathrm{~nm}$ ambient aerosol measured for approximately two weeks in central Manchester by the HTDMA-SP2. The top panel shows $\kappa$ for $\mathrm{rBC}$-containing particles only, the middle panel shows $\kappa$ values for purely scattering particles and the bottom panel shows $\kappa$ of the sum of $\mathrm{rBC}$ and purely scattering particle.

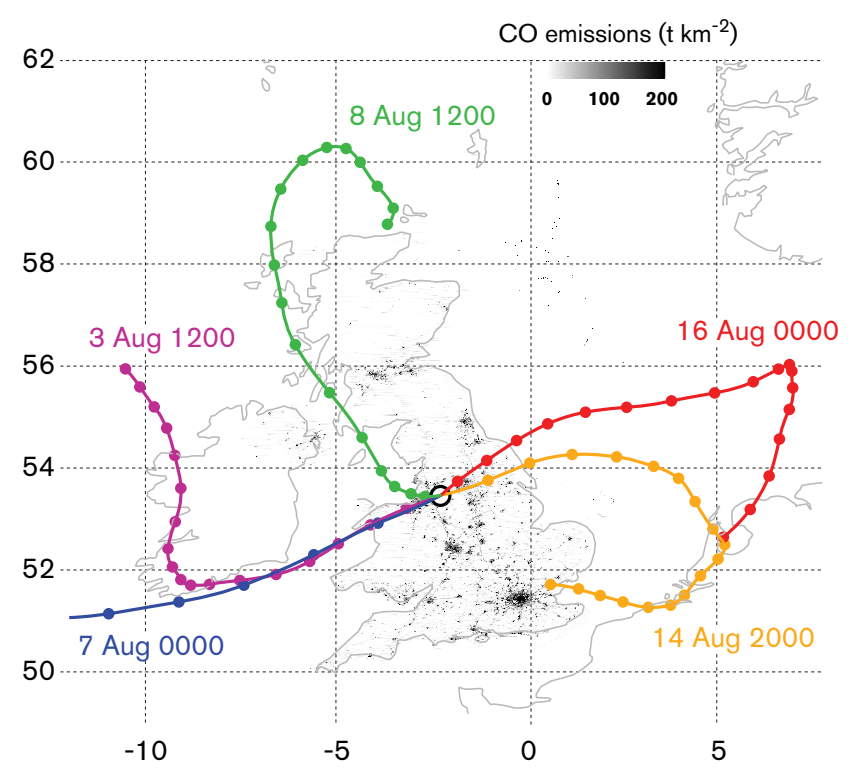

Fig. 5. Selected air parcel backwards trajectories computed from the NOAA HYSPLIT model (Draxler and Rolph, 2010) during ambient Manchester sampling in 2010 superimposed on the UK National Atmospheric Emissions Inventory carbon monoxide emissions inventory for year 2008. The arrival date and time of each trajectory is indicated and points are separated by three hours.

did not pass over large $\mathrm{rBC} / \mathrm{CO}$ source regions, unlike those approaching from the east and south, which were also influenced by continental Europe. Therefore we believe that samples taken towards the end of the study period contained BC that experienced longer processing times in the atmosphere.

\section{Discussion}

\subsection{Relationships with rBC mixing state}

We examined the relationships between several estimates of rBC coating thickness and mixing state for hydrophobic and hygroscopic rBC particles. Ideally, coating thickness could be quantitatively related to $\mathrm{rBC}$ particle hygroscopicity, but uncertainties in the rBC effective density $\left(\rho_{\mathrm{e}}\right)$ (shape, porosity), optical properties, composition and density of coating and emissivity of rBC limit how quantitatively these relationships can be determined.

The relationship between $\mathrm{rBC}$ mass $\left(m_{\mathrm{BC}}\right)$ mobility diameter $\left(D_{\mathrm{mob}}\right)$ and effective density is given by

$\rho_{\mathrm{e}}=\frac{6}{\pi} \frac{m_{\mathrm{BC}}}{D_{\mathrm{mob}}^{3}}$

The effective density depends on the morphology of the rBC particles and increases for more compact particles. We calculated a mobility-based coating thickness $\left(\mathrm{CT}_{\mathrm{mob}}\right)$

$C T_{\mathrm{mob}}=\frac{1}{2}\left(D_{\mathrm{mob}}-\sqrt[3]{\frac{6}{\pi} \frac{m_{\mathrm{BC}}}{\rho_{\mathrm{e}}}}\right)$

where it is assumed that the effective density at low $g f$ particles is the same for all $g f$. We estimated $\rho_{\mathrm{e}} \approx 1-1.5 \mathrm{~g} \mathrm{~cm}^{-3}$ for the laboratory standards and $\rho_{\mathrm{e}} \approx 0.6 \mathrm{~g} \mathrm{~cm}^{-3}$ for ambient samples at $g f=1$ by assuming there was no coating associated with these $\mathrm{rBC}$ particles (setting $\mathrm{CT}_{\text {mob }}=0$ ) and solving Eq. (4) for $\rho_{\mathrm{e}}$. The lower ambient $\rho_{\mathrm{e}}$ suggested these particles were more fractal and less compact compared to the laboratory standards. Moteki and Kondo (2010) reported a similar discrepancy between laboratory generated $\mathrm{rBC}$ and 
ambient $\mathrm{rBC}$ measured in Tokyo and also measured a similar effective density $\left(\rho_{\mathrm{e}} \approx 0.5 \mathrm{~g} \mathrm{~cm}^{-3}\right.$ for $\left.D_{\mathrm{mob}}=200 \mathrm{~nm}\right)$ for the ambient rBC.

We calculated $\mathrm{CT}_{\text {mob }}$ at higher $g f$ by assuming $\rho_{\mathrm{e}}$ was constant and show results for selected laboratory-generated and ambient $g f$ scans in Figs. 2 and 3. Note that if $\rho_{\mathrm{e}}$ was actually lower than the $\rho_{\mathrm{e}}=0.6 \mathrm{~g} \mathrm{~cm}^{-3}$ obtained at $g f=1$ for $\mathrm{rBC}$ particles measured at higher $g f$, Eq. (4) would over-predict the true coating thickness and vice versa if $\rho_{\mathrm{e}}$ were higher. For example, we observed an increase $\mathrm{CT}_{\text {mob }}$ of approximately $25 \mathrm{~nm}$ for $g f=1.6$ for the scan shown in Fig. $3 \mathrm{~g}$, which requires an $\rho_{\mathrm{e}} \approx 0.25 \mathrm{~g} \mathrm{~cm}^{-3}$ to obtain the same $D_{\text {mob }}=193 \mathrm{~nm}$ if no coating was present. We believe it more likely that the $\mathrm{rBC}$ cores for coated, hygroscopic particles collapsed to a more compact shape (Alexander et al., 2008; Zhang et al., 2008; Lewis et al., 2009; Pagels et al., 2009), resulting in a higher $\rho_{\mathrm{e}}$ and an underestimate of the true coating thickness by Eq. (4). We did not expect $\rho_{\mathrm{e}}$ for the laboratory proxy rBC species we tested to change following mixing with other material because they were not fractal aggregates. The presence of coatings do not affect the determination of $m_{\mathrm{BC}}$ by the SP2 other than the possibility that the some coatings for small $\mathrm{rBC}$ cores may be too thick to completely evaporate in the laser beam (Slowik et al., 2007; Schwarz et al., 2008).

We also used two additional estimates of $\mathrm{rBC}$ coating thickness and mixing state to compare high and low $g f \mathrm{rBC}$ particles and compared the results to $\mathrm{CT}_{\text {mob}}$. We calculated the number fraction of thickly coated particles based on the distribution of delay times measured for $\mathrm{rBC}$ particles by the $\mathrm{SP} 2$. The optical coating thickness $\left(\mathrm{CT}_{\mathrm{opt}}\right)$ was calculated using Eq. (4) but replacing $D_{\text {mob }}$ with the PSL-equivalent optical diameter determined from the SP2 light scattering measurement. Both of these estimates also increased with higher $g f$ for both laboratory-generated and ambient samples. If the $\kappa$ of the coating is known or assumed, then the $g f$ themselves can be used to obtain an estimate of the coating thickness by solving Eq. (2) for the volume fraction of the coating assuming a core-and-shell morphology and $\kappa=0$ for $\mathrm{rBC}$. Thus the HTDMA-SP2 system can provide three different estimates of coating thickness based on the relationships between $m_{\mathrm{BC}}$ and (a) mobility $\left(\mathrm{CT}_{\mathrm{mob}}\right)$, (b) $\mathrm{rBC}$ optical size $\left(\mathrm{CT}_{\mathrm{opt}}\right)$ and (c) hygroscopicity $\left(\mathrm{CT}_{\kappa}\right)$. Each estimate has inherent uncertainties associated with particle shape and composition, but may be helpful in constraining predicted and measured $\mathrm{rBC}$ properties through closure approaches. The HTDMA-SP2 could be combined with independent measures of coating mass, such as the DMA-aerosol particle mass analyzer technique used by Pagels et al. (2009) and Khalizov et al. (2009), to investigate the conditions for which the HTDMA-SP2 coating thickness estimates can be used with confidence.

\subsection{Refractory black carbon "age"}

Most of the ambient rBC cores were not coated and did not take up water. A relatively small fraction of the particles were coated with up to $20 \mathrm{~nm}$ thick layers as determined from the $\mathrm{CT}_{\text {mob }}$ measurements (e.g., Fig. 3g). These particles took up water and had a mode with an overall $\kappa \sim 0.2-0.4$ (Fig. 3). Should those particles be considered as aged, i.e. CCN active, in atmospheric models? Recalling our treatment of BC age from Sect. 2, we first quantify the relationship between the $\mathrm{rBC}$ core mass equivalent diameter $\left(D_{\mathrm{BC}}\right)$, coating thickness, and critical supersaturation. The critical supersaturation required to activate a particle depends on the dry diameter and its $\kappa$. If a threshold supersaturation is defined (e.g. $s=0.2 \%$ for stratus cloud conditions), the core diameter is known, and a value for $\kappa$ of the coating is assumed, it is conceptually straightforward to find the critical coating thickness, defined as the thickness that is required to make the core $\mathrm{CCN}$ active. Note that coating a BC core will simultaneously increase the particle diameter and overall $\kappa$ through the mixing rule given in Eq. (2), thereby necessitating an iterative procedure.

Calculated critical coating thicknesses are shown in Fig. 6 for a number of threshold supersaturations and assumed $\kappa$ 's of the coating material. Also shown are two representative size distributions for $\mathrm{rBC}$ cores measured by Schwarz et al. (2008) to aid the interpretation. As expected from theory, smaller particles require larger coatings to meet the "aged" threshold. In the extreme case of $D_{\mathrm{BC}}=50 \mathrm{~nm}, s=0.1 \%$, $\kappa=0.1$, the coating thickness that is required is $\sim 100 \mathrm{~nm}$. Overall this corresponds to a $250 \mathrm{~nm}$ diameter particle which is completely dominated in mass by the coating material. In the other extreme $D_{\mathrm{BC}}=300 \mathrm{~nm}, s=1 \%, \kappa=0.6$ a coating thickness of $\sim 0.1 \mathrm{~nm}$ is sufficient to age the particle. Figure 6 can be used as state space to identify if a particular particle/coating combination is aged. For example consider an $\mathrm{rBC}$ particle with $D_{\mathrm{BC}} \sim 170 \mathrm{~nm}$ and a $\mathrm{CT}_{\text {mob }} \sim 20 \mathrm{~nm}$ and its location in the state space suggests that this particular particle is sufficiently coated to activate at $s=0.1-0.2 \%$, depending on the $\kappa$ value of the coating. The critical coating thickness is surprisingly sensitive to the $\kappa$ of the coating material, and hence the chemical composition of the coatings. The case study illustrates that taken in isolation neither coating thickness nor the measured $\mathrm{rBC} \kappa$ distributions are sufficient to diagnose the hydrophobic-to-hydrophilic conversion in the atmosphere.

\subsection{Ambient rBC measurements}

We calculated the number fraction of "aged" rBC particles $\left(F_{\text {aged }}\right)$ using the previously discussed aging framework, treating all $\mathrm{rBC}$ particles with $\kappa$ greater than that needed to activate at $s=0.2 \%$ as aged. The calculation of $F_{\text {aged }}$ from ambient data requires the assumption that $\kappa$ from subsaturated measurements can be extrapolated to supersaturated conditions and that $D_{\text {mob }}$ approximates the sphere equivalent 


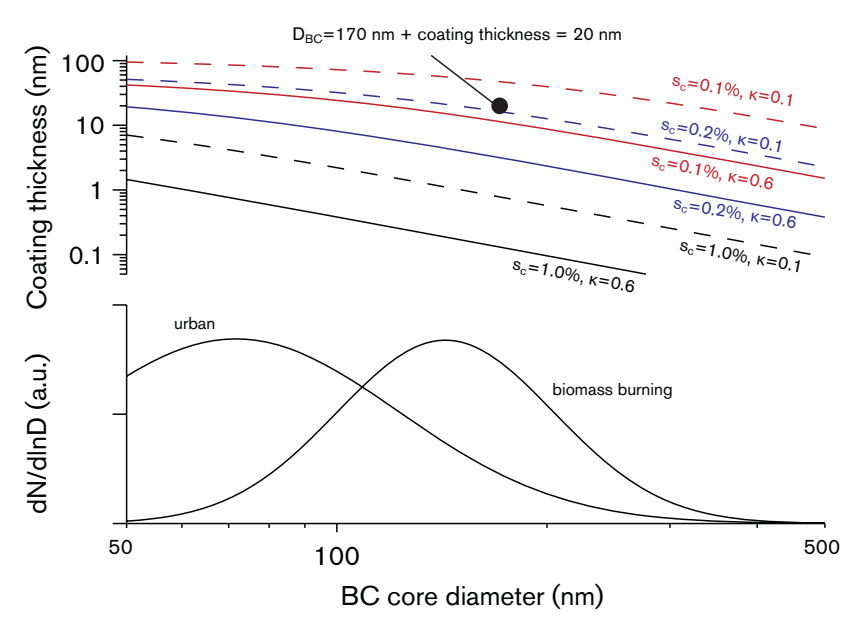

Fig. 6. Bottom plot: number distribution of refractory BC cores size distribution measured in fresh urban and biomass burning plumes reported by Schwarz et al. (2008). Top plot: coating thickness that a soot core must acquire before it can serve as CCN. Black, blue and red colors indicate the $1 \%, 0.2 \%$, and $0.1 \%$ supersaturation threshold. Solid lines and dashed lines are computed assuming that $\kappa$ of the coating material is 0.6 or 0.1 , respectively.

diameter. Laboratory studies suggest that these assumptions are sufficient (Henning et al., 2010) but they should be scrutinized in future studies that also include a CCN instrument. Figure 7a shows $F_{\text {aged }}$ measured in Manchester during the ambient sampling period. $F_{\text {aged }}$ remained low $(<0.05)$ and relatively constant for the first eight days of measurements, which were dominated by westerly flow and featured several precipitation events. $F_{\text {aged }}$ increased to $\sim 0.25$ during the last two days of measurements, starting at around midday on the 14 August. This coincided with the shift in wind direction from west to east and backwards trajectories passing over continental Europe and north-eastern England (Fig. 5). We attribute the increase in $F_{\text {aged }}$ to the change in transport pattern. Previous airborne measurements over the UK have shown evidence of more aged aerosol associated with easterly transport from continental Europe (e.g., Morgan et al., 2010).

The overall low fraction of $F_{\text {aged }}$ observed throughout the observation period (typically less than $10 \%$ ) reflected the importance of local urban $\mathrm{rBC}$ sources in close proximity to the measurement site. Even when long-range transport patterns shifted to bring continental pollution over the UK, it was super-imposed on the emissions from local sources in Manchester. The importance of local sources was also reflected by the nearly continuous presence of the nonhygroscopic $\mathrm{rBC}$ mode throughout the measurement campaign. There was more variability in the hygroscopic mode, which was dominated by non-rBC particles and reflected contributions by both primary and secondary sources.

Riemer et al. (2010) characterized $F_{\text {aged }}$ inferred aging time scales using a plume model. Jacobson (2010) calcu- lated an approximately $3 \mathrm{~h}$ e-folding lifetime for externally mixed $\mathrm{BC}$ primarily due to coagulation using a global climate model. He further calculated an internally mixed BC lifetime of 4.7 days. The HTDMA-SP2 method can be used in principle to validate these types of models if a lagrangian experiment design is implemented or the age of the black carbon particles could be ascertained. Moffett and Prather (2009) measured a soot/BC aging time of 3 hours in Mexico City based on chemical and optical transformations measured using single particle mass spectrometry. This may differ from a timescale based on $\mathrm{CCN}$ activation criteria presented here that applies more directly to $\mathrm{BC}$ lifetime questions.

The HTDMA-SP2 measurements also provided an opportunity to examine the composition of hydrophobic particles in that we could determine the fraction containing rBC. The HTDMA-SP2 measurements in urban Manchester showed that on average $\sim 25 \%$ of the hydrophobic particles do not contain any detectable concentrations of rBC (Fig. 7b). We suspect these particles were composed primarily of hydrocarbon-like organic aerosol (HOA), which has been measured by aerosol mass spectrometers at a number of urban locations, including Manchester (Zhang et al., 2005). This was expected because combustion processes that are responsible for $\mathrm{BC}$ emissions also emit particles that are composed of hydrophobic non-polar non-absorbing high molecular weight hydrocarbons (Saxena and Hildemann, 1996; Simoneit, 2002) which are typically described by $\kappa=0$. It is encouraging that the HTDMA-SP2 measurements may be able to probe the mechanisms by which these non-hygroscopic, but non-rBC particles are processed.

\subsection{Pathways to $\mathrm{rBC}$ coating and removal}

Refractory BC particles may acquire coatings or otherwise become mixed with hygroscopic material and/or be scavenged through several different mechanisms. The most simple and that addressed most clearly in our current study is the nucleation scavenging pathway, in which a non-hygroscopic rBC particle becomes coated and CCN active at a specific supersaturation. Partially coated or non-coated rBC particles may also coagulate with hygroscopic particles or be scavenged by existing cloud droplets. If the cloud droplet evaporates the remaining hygroscopic residue would include the $\mathrm{rBC}$ particle.

The HTDMA-SP2 approach cannot distinguish between rBC particles that have acquired coatings through any of these mechanisms. The interpretation of the results requires some idea of the air mass history, such as whether it was likely to have been cloud processed prior to sampling. The method would be useful in examining the importance of different scavenging methods in that it would be able to probe how hydrophobic and hygroscopic rBC particles are affected by a precipitation event at the measurement location or the presence of cloud at a higher elevation site. Our limited 


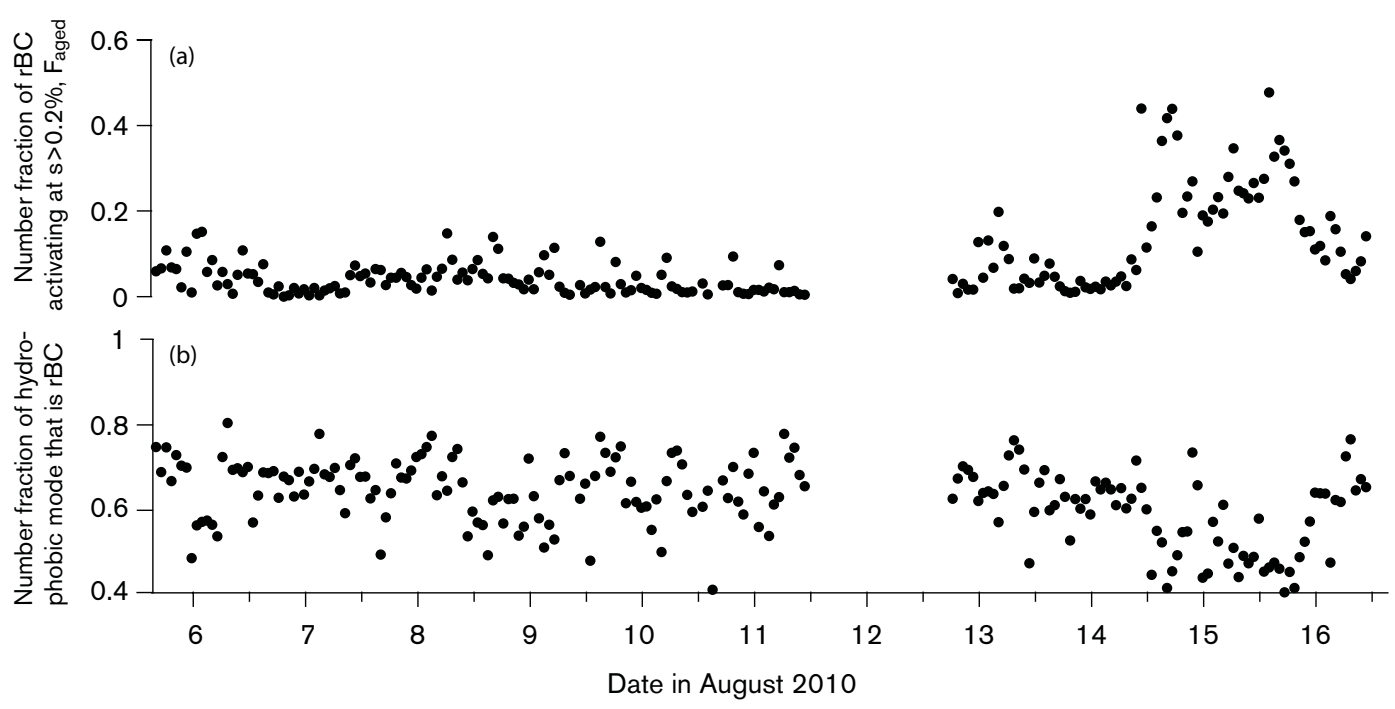

Fig. 7. Number fraction of $\mathrm{rBC}$-containing particles that are $\mathrm{CCN}$ active at a supersaturation $0.2 \%$ for mixed particle dry mobility diameters of $193 \mathrm{~nm}$ as a function of time (a) and the number fraction of 193nm non-CCN active particles that contain $\mathrm{rBC}$ (b) observed during the ambient Manchester sampling between 5 and 16 August 2010. Only periods when the HTDMA-SP2 system was operating at $90 \%$ RH are shown.

measurements in the current study are insufficient to make larger conclusions about the role of various scavenging and $\mathrm{rBC}$ mixing processes, but we believe additional measurements with similar systems in a range of location would be able to provide much more insight.

\subsection{Implications for SP2-only rBC measurements}

The SP2 is also capable of obtaining independent information regarding the $\mathrm{rBC}$ mixing state through the analysis of the scattering and incandesence signals for single rBCcontaining particles (e.g., Gao et al., 2007; Shiraiwa et al., 2007). These approaches have widely been used in the SP2 community to evaluate the mixing state of $\mathrm{rBC}$ (Schwarz et al., 2006, 2008 Baumgardner et al., 2007; Shiraiwa et al., 2007; Subramanian et al., 2010). Schwarz et al. (2008) used the SP2 to contrast rBC in urban and biomass burning dominated rural airsheds and found thinner coatings and smaller number fractions of coated particles in the urban sample. The number fraction of coated particles also increases by $\sim 1.9 \% \mathrm{~h}^{-1}$ in the plume downwind of Tokyo, Japan (Shiraiwa et al., 2007), with sulfate and organics being the main contributors to the coatings.

We investigated whether the traditional SP2-only mixing state measurements could be related to $\mathrm{rBC}$ hygroscopicity. Figure 8 shows an example of the SP2 coating information for ambient Manchester aerosol HTDMA-SP2 scans between 11-16 August. We excluded multiply-charged particles from the coating analysis. Nearly all of the rBC particles detected in the hygroscopic mode $(g f>1.2)$ were classified as "thickly coated" using the time delay criterion, consistent with the need for additional material to compensate for the reduced $\mathrm{rBC}$ mass while maintaining a $D_{\text {mob }}=193 \mathrm{~nm}$. The average optically-derived coating thickness also remained constant for $g f<1.2$ before increasing to approximately $40 \mathrm{~nm}$ for higher $g f$. The coating thickness inferred from the decrease in rBC mean diameter for the scan was approximately $15 \mathrm{~nm}$. Direct comparison of optically- and mobilityderived coating thicknesses requires information about the refractive index of the $\mathrm{rBC}$ core and coating to convert scattering measurements to physical size (e.g., Schwarz et al., 2008). The presence of the water on the particles may also lead to an overestimate of the coating thickness, but this could be eliminated by adding an active drying system between the HTDMA and SP2 inlet which was missing in our setup.

Previous studies involving the SP2 have speculated that the addition of hygroscopic material to $\mathrm{rBC}$ particles during aging processes would increase the $\mathrm{rBC}$ hygroscopicity. The good relationship between different SP2-derived indicators of coatings shows that SP2 measurements may give an independent measure of $\mathrm{rBC}$ hygroscopicity, provided size/coating relationships such as presented in Fig. 6 are taken into account.

\section{Conclusions}

We have developed and tested a coupled HTDMA-SP2 system for measuring refractory black carbon $(\mathrm{rBC})$ aerosol hygroscopicity. The HTDMA-SP2 distinguished $\mathrm{rBC}$ from "purely scattering" particles in laboratory and ambient sampling. We found that three different laboratory-generated rBC proxy materials, glassy carbon spheres, aquadag and 

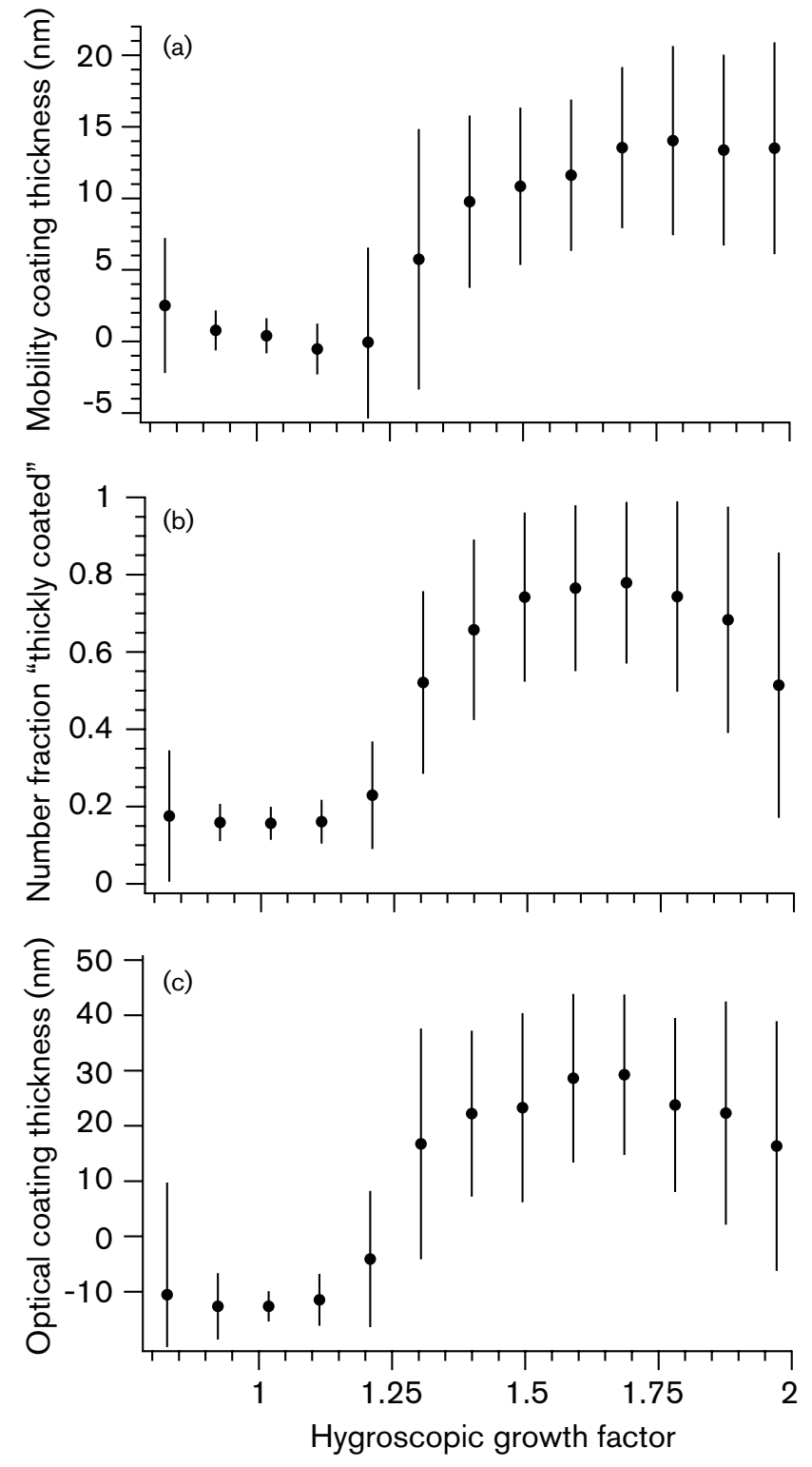

Fig. 8. SP2-derived coating information for HTDMA-SP2 scans for ambient Manchester rBC between 11-16 August 2010. Shown are the mean and standard deviations binned by growth factor for mobility-derived coating thickness (a), number fraction of thickly coated rBC particles (b), and optically derived coating thickness (c).

carbon black, had $g f \sim 1$ and higher $g f$ for carbon black mixed with two different hygroscopic compounds. Ambient sampling near central Manchester showed the majority of rBC-containing particles were non-hygroscopic, with only $5-10 \%$ having $g f>1.2$. The hygroscopic fraction increased following a change in transport pattern from the west (maritime Atlantic) to the east (continental polluted). Three independent qualitative measures of rBC mixing state (mean rBC core size, number fraction of "thickly coated" particles, and leading edge only inferred coating thickness) showed clear differences between hygroscopic and non-hygroscopic rBC particles for both laboratory-generated and ambient samples. We used the single parameter framework to estimate the number fraction of aged particles, i.e. particles that can undergo nucleation scavenging in clouds, and found that the aged fraction seemed to be controlled by the history of the airmass and was consistent with a mixture of local and regional sources. Future studies should combine this method with a measure of physical or photochemical age to provide quantitative estimates for characterizing hydrophobicto-hydrophilic conversion rates in the atmosphere.

Acknowledgements. This work was supported by the NERC grant Multiscale Chemical Composition of Carbonaceous particles and Coatings (MC4), NE/H008136/1. Author contributions: M. D. P. and G. R. M. designed research; N. G. and G. R. M. performed research; H. C. and G. M. supported the research, provided equipment and guidance; N. G., G. R. M. and M. D. P. analyzed data and G. R. M., M. D. P., N. G., H. C. and G. M. wrote the paper. We thank Michael Flynn for providing ceilometer data, his input on the experiments and general support for the SP2 and James Whitehead for his assistance during the ambient sampling. Carbon monoxide emission data were provided by the UK National Atmospheric Emission Inventory website (http://www.naei.org.uk/index.php), which is supported in part by the UK Department for Environment, Food and Rural Affairs. We also thank two anonymous reviewers for their comments and suggestions.

Edited by: M. C. Facchini

\section{References}

Alexander, D. T. L., Crozier, P. A., and Anderson, J. R.: Brown carbon spheres in East Asian outflow and their optical properties, Science, 321, 833-836, doi:10.1126/science.1155296, 2008.

Baumgardner, D., Kok, G., and Raga, G.: Warming of the Arctic lower stratosphere by light absorbing particles, Geophys. Res. Lett., 31, L06117, doi:10.1029/2003GL018883, 2004.

Baumgardner, D., Kok, G. L., and Raga, G. B.: On the diurnal variability of particle properties related to light absorbing carbon in Mexico City, Atmos. Chem. Phys., 7, 2517-2526, doi:10.5194/acp-7-2517-2007, 2007.

Chung, S. H. and Seinfeld, J. H.: Global distribution and climate forcing of carbonaceous aerosols, J. Geophys. Res., 107, D4407, doi:10.1029/2001JD001397, 2002.

Cooke, W. F. and Wilson, J. J. N.: A global black carbon aerosol model, J. Geophys. Res., 101, 19395-19409, 1996.

Cubison, M. J., Coe, H., and Gysel, M.: A modified hygroscopic tandem DMA and a data retrieval method based on optimal estimation, J. Aerosol Sci., 36, 846-865, 2005.

Draxler, R. R. and Rolph, G. D.: HYSPLIT (HYbrid Single-Particle Lagrangian Integrated Trajectory) Model access via NOAA ARL READY Website, available at: http://ready.arl.noaa.gov/ HYSPLIT.php, NOAA Air Resources Laboratory, Silver Spring, MD, 2010. 
Dusek, U., Reischl, G. P., and Hitzenberger, R.: CCN activation of pure and coated carbon black particles, Environ. Sci. Technol., 40, 1223-1230, 2006.

Fletcher, N. H.: Size effects in heterogeneous nucleation, J. Chem. Phys., 29, 572-576, 1958.

Gao, R. S., J. P. Schwarz, K. K., Kelly, D. W., Fahey, L. A., Watts, T. L., Thompson, J. R., Spackman, J. G., Slowik, E. S., Cross, J.-H., Han, P., Davidovits, T. B., Onasch, and Worsnop, D. R.: A novel method for estimating light-scattering properties of soot aerosols using a modified single-particle soot photometer, Aerosol Sci. Technol., 41, 125-135, doi:10.1080/02786820601118398, 2007.

Good, N., Topping, D. O., Duplissy, J., Gysel, M., Meyer, N. K., Metzger, A., Turner, S. F., Baltensperger, U., Ristovski, Z., Weingartner, E., Coe, H., and McFiggans, G.: Widening the gap between measurement and modelling of secondary organic aerosol properties?, Atmos. Chem. Phys., 10, 2577-2593, doi:10.5194/acp-10-2577-2010, 2010.

Gysel, M., Nyeki, S., Weingartner, E., Baltensperger, U., Giebl, H., Hitzenberger, H., Petzold, A., and Wilson, C. W.: Properties of jet engine combustion particles during the PartEmis experiment: Hygroscopicity at subsaturated conditions, Geophys. Res. Lett., 30, 1566, doi:10.1029/2003GL016896, 2003.

Gysel, M., McFiggans, G. B., and Coe, H.: Inversion of tandem differential mobility analyser (TDMA) measurements, J. Aerosol Sci., 40, 134-151, 2009.

Henning, S., Wex, H., Wennrich, C., Hennig, T., Kiselev, A., Snider, J. R., Rose, D., Dusek, U., Frank, G. P., Pöschl, U., Kristensson, A., Bilde, M., Tillmann, R., Kiendler-Scharr, A., Mentel, Th. F., Walter, S., Schneider, J., and Stratmann, F.: Soluble mass, hygroscopic growth, and droplet activation of coated soot particles during LACIS Experiment in November (LExNo), J. Geophys. Res., 115, D11206, doi:10.1029/2009JD012626, 2010.

Henson, B. F.: An adsorption model of insoluble particle activation: Application to black carbon, J. Geophys. Res., 112, D24S16, doi:10.1029/2007JD008549, 2007.

Herich, H., Kammermann, L., Gysel, M., Weingartner, E., Baltensperger, U., Lohmann, U., Cziczo, D. J.: In situ determination of atmospheric aerosol composition as a function of hygroscopic growth, J. Geophys. Res., 113, D16213, doi:10.1029/2008JD009954, 2008.

Junge, C., : Das Wachstum der Kondensationskerne mit der relativen Feuchtigkeit, Annalen der Meteorologie, 3, 129-135, 1950.

Kanakidou, M., Seinfeld, J. H., Pandis, S. N., Barnes, I., Dentener, F. J., Facchini, M. C., Van Dingenen, R., Ervens, B., Nenes, A., Nielsen, C. J., Swietlicki, E., Putaud, J. P., Balkanski, Y., Fuzzi, S., Horth, J., Moortgat, G. K., Winterhalter, R., Myhre, C. E. L., Tsigaridis, K., Vignati, E., Stephanou, E. G., and Wilson, J.: Organic aerosol and global climate modelling: a review, Atmos. Chem. Phys., 5, 1053-1123, doi:10.5194/acp-5-1053-2005, 2005.

Khalizov, A. F, Zhang, R., Zhang, D., Xue, H., Pagels, J., and McMurry, P. H.: Formation of highly hygroscopic soot aerosols upon internal mixing with sulfuric acid vapor, J. Geophys. Res., 114, D05208, doi:10.1029/2008JD010595, 2009.

Koch, D.: Transport and direct radiative forcing of carbonaceous and sulfate aerosols in the GISS GCM, J. Geophys. Res., 106, 20311-20332, 2001.

Koch, D., Schulz, M., Kinne, S., McNaughton, C., Spackman, J. R., Balkanski, Y., Bauer, S., Berntsen, T., Bond, T. C., Boucher,
O., Chin, M., Clarke, A., De Luca, N., Dentener, F., Diehl, T., Dubovik, O., Easter, R., Fahey, D. W., Feichter, J., Fillmore, D., Freitag, S., Ghan, S., Ginoux, P., Gong, S., Horowitz, L., Iversen, T., Kirkevåg, A., Klimont, Z., Kondo, Y., Krol, M., Liu, X., Miller, R., Montanaro, V., Moteki, N., Myhre, G., Penner, J. E., Perlwitz, J., Pitari, G., Reddy, S., Sahu, L., Sakamoto, H., Schuster, G., Schwarz, J. P., Seland, Ø., Stier, P., Takegawa, N., Takemura, T., Textor, C., van Aardenne, J. A., and Zhao, Y.: Evaluation of black carbon estimations in global aerosol models, Atmos. Chem. Phys., 9, 9001-9026, doi:10.5194/acp-9-9001-2009, 2009.

Koehler, K. A., DeMott, P. J., Kreidenweis, S. M., Popovicheva, O., Petters, M. D., Carrico, C. M., Kireeva, E., Khokhlova, T., and Shonija, N.: Cloud condensation nuclei and ice nucleation activity of hydrophobic and hydrophilic soot particles, Phys. Chem. Chem. Phys., 11, 7906-7920, doi:10.1039/b905334b, 2009.

Lammel, G. and Novakov, T.: Water nucleation properties of carbon-black and diesel soot particles, Atmos .Environ., 29, 813823, 1995.

Lewis, K. A., Arnott, W. P., Moosmüller, H., Chakrabarty, R. K., Carrico, C. M., Kreidenweis, S. M., Day, D. E., Malm, W. C., Laskin, A., Jimenez, J. L., Ulbrich, I. M., Huffman, J. A., Onasch, T. B., Trimborn, A., Liu, L., and Mishchenko, M. I.: Reduction in biomass burning aerosol light absorption upon humidification: roles of inorganically-induced hygroscopicity, particle collapse, and photoacoustic heat and mass transfer, Atmos. Chem. Phys., 9, 8949-8966, doi:10.5194/acp-9-8949-2009, 2009.

Liu, D., Flynn, M., Gysel M., Targino, A., Crawford, I., Bower, K., Choularton, T., Juranyi, Z., Steinbacher, M., Huglin, C., Curtius, J., Kampus, M., Petzold, A., Weingartner, E., Baltensperger, U., and Coe, H.: Single particle characterization of black carbon aerosols at a tropospheric alpine site in Switzerland, Atmos. Chem. Phys., 10, 7389-7407, doi:10.5194/acp-10-7389-2010, 2010.

Mahata, P. C. and Alofs, D. J.: Insoluble condensation nuclei: The effect of contact angle, surface roughness and adsorption, J. Atmos. Sci., 32, 116-122, 1975.

McMeeking, G. R., Hamburger, T., Liu, D., Flynn, M., Morgan, W. T., Northway, M., Highwood, E. J., Krejci, R., Allan, J. D., Minikin, A., and Coe, H.: Black carbon measurements in the boundary layer over western and northern Europe, Atmos. Chem. Phys., 10, 9393-9414, doi:10.5194/acp-10-9393-2010, 2010.

Moffet, R. C. and Prather, K. A.: In-situ measurements of the mixing state and optical properties of soot with implications for radiative forcing estimates, P. Natl. Acad. Sci. USA, 106(29), 11872-11877, 2009.

Morgan, W. T., Allan, J. D., Bower, K. N., Esselborn, M., Harris, B., Henzing, J. S., Highwood, E. J., Kiendler-Scharr, A., McMeeking, G. R., Mensah, A. A., Northway, M. J., Osborne, S., Williams, P. I., Krejci, R., and Coe, H.: Enhancement of the aerosol direct radiative effect by semi-volatile aerosol components: airborne measurements in North-Western Europe, Atmos. Chem. Phys., 10, 815-1-8171, doi:10.5194/acp-10-8151-2010, 2010.

Moteki, N. and Kondo, Y.: Dependence of laser-induced incandescence on physical properties of black carbon aerosols: Measurements and theoretical interpretation, Aerosol Sci. Tech., 44, 663675, doi:10.1080/02786826.2010.484450, 2010. 
Moteki, N., Kondo, Y., Miyazaki, Y., Takegawa, N., Komazaki, Y., Kurata, G., Shirai, T., Blake, D. R., Miyakawa, T., and Koike, M.: Evolution of mixing state of black carbon particles: Aircraft measurements over the western Pacific in March 2004, Geophys. Res. Lett., 34, L11803, doi:10.1029/2006GL028943, 2007.

Moteki, N., Kondo, Y., and Nakamura, S.: Method to measure refractive indices of small nonspherical particles: Application to black carbon particles, J. Aerosol Sci., 41, 513-521, doi:10.1016/j.jaerosci.2010.02.013, 2010.

Pagels, J., Khalizov, A. F., McMurry, P. H., and Zhang, R. Y.: Processing of soot by controlled sulphuric acid and water condensation-Mass and mobility relationships, Aerosol Sci. Technol., 43(7), 629-640, 2009.

Petters, M. D. and Kreidenweis, S. M.: A single parameter representation of hygroscopic growth and cloud condensation nucleus activity, Atmos. Chem. Phys., 7, 1961-1971, doi:10.5194/acp-71961-2007, 2007.

Petters, M. D. and Kreidenweis, S. M.: A single parameter representation of hygroscopic growth and cloud condensation nucleus activity - Part 2: Including solubility, Atmos. Chem. Phys., 8, 6273-6279, doi:10.5194/acp-8-6273-2008, 2008.

Petters, M. D., Prenni, A. J., Kreidenweis, S. M., DeMott, P. J., Matsunaga, A., Lim, Y. B., and Ziemann, P. J.: Chemical aging and the hydrophobic-to-hydrophilic conversion of carbonaceous aerosol, Geophys. Res. Lett., 33, L24806, doi:10.1029/2006GL027249, 2006.

Popovicheva, O. B., Persiantseva, N. M., Tishkova, V., Shonija, N. K., and Zubareva, N. A.: Quantification of water uptake by soot particles, Environ. Res. Lett., 3, 025009, doi:10.1088/17489326/3/2/025009, 2008a.

Popovicheva, O., Persiantseva, N. M., Shonija, N. K., DeMott, P. J., Koehler, K. A., Petters, M. D., Kreidenweis, S. M., Tishkova, V., Demirdjian, B., and Suzanne, J.: Water interaction with hydrophobic and hydrophilic soot particles, Phys. Chem. Chem. Phys., 10(17), 2332-2344, 2008b.

Pratt, K. A., and Prather, K. A.: Aircraft measurements of vertical profiles of aerosol mixing states, J. Geophys. Res., 115, D11305, doi:10.1029/2009JD013150, 2010.

Pruppacher, H. R., and Klett, J. R.: Microphysics of Clouds and Precipitation, 1997.

Rader, D. J. and McMurry, P. H.: Application of the Tandem Differential Mobility Analyzer to studies of droplet growth or evaporation, J. Aerosol Sci., 17, 771-787, 1986.

Ramanathan, V. and Carmichael, G.: Global and regional climate changes due to black carbon, Nat. Geosci., 1, 221-2-27, doi:10.1038/ngeo156, 2008.

Riemer, N., West, M., Zaveri, R. A., and Easter, R. C.: Estimating black carbon aging time scales with a particleresolved aerosol model, J. Aerosol Sci., 41, 143-158, doi:10.1016/j.jaerosci.2009.08.009, 2010.

Rodhe, H., Persson, C., and Akesson, O.: An investigation into regional transport of soot and sulfate aerosols, Atmos. Environ., 6, 675-693, 1972.

Saxena, P. and Hildemann, L. M.: Water-soluble organics in atmospheric particles: A critical review of the literature and application of thermodynamics to identify candidate compounds, J. Atmos. Chem., 24, 57-109, 1996.

Schwarz, J. P., Gao, R. S., Fahey, D. W., Thomson, D. S., Watts, L. A., Wilson, J. C., Reeves, J. M., Darbeheshti, M., Baum- gardner, D. G., Kok, G. L., Chung, S. H., Schulz, M., Hendricks, J., Lauer, A., Karcher, B., Slowik, J. G., Rosenlof, K. H., Thompson, T. L., Langford, A. O., Loewenstein, M., and Aikin, K. C.: Single-particle measurements of midlatitude black carbon and light-scattering aerosols from the boundary layer to the lower stratosphere, J. Geophys. Res., 111, D16207, doi:10.1029/2006JD007076, 2006.

Schwarz, J. P., Gao, R. S., Spackman, J. R., Watts, L. A., Thomson, D. S., Fahey, D. W., Ryerson, T. B., Peischl, J., Holloway, J. S., Trainer, M., Frost, G. J., Baynard, T., Lack, D. A., de Gouw, J. A., Warneke, C., and Del Negro, L. A.: Measurement of the mixing state, mass, and optical size of individual black carbon particles in urban and biomass burning emissions, Geophys. Res. Lett., 35, L13810, doi:10.1029/2008GL033968, 2008.

Schwarz, J. P., Spackman, J. R., Gao, R. S., Perring, A. E., Cross, E., Onasch, T. B., Ahern, A., Wrobel, W., Davidovits, P., Olfert, J., Dubey, M. K., Mazzoleni, C., and Fahey, D. W.: The detection efficiency of the Single Particle Soot Photometer, Aerosol Sci. Technol., 44, 612-628, doi:10.1080/02786826.2010.481298, 2010.

Shiraiwa, M., Kondo, Y., Moteki, N., Taegawa, N., Miyazaki, Y., and Blake, D. R.: Evolution of mixing state of black carbon in polluted air from Tokyo, Geophys. Res. Lett., 34, L16803, doi:10.1029/2007GL029819, 2007.

Simoneit, B. R. T.: Biomass burning - A review of organic tracers for smoke from incomplete combustion, Appl. Geochem., 17, 129-162, 2002.

Slowik, J. G., Cross, E. S., Han, J.-H., Davidovits, P., Onasch, T. B., Jayne, J. T., Williams, L. R., Canagaratna, M. R., D. R., Chakrabarty, R. K., Moosmuller, H., Arnott, W. P., Schwarz, J. P., Gao, R. S., Fahey, D. W., Kok, G. L., and Petzold, A.: An inter-comparison of instruments measuring black carbon content of soot particles, Aerosol Sci. Technol., 41, 295-314,Worsnop, doi:10.1080/02786820701197078, 2007.

Snider, J. R., Guibert, S., Brenguier, J. L., and Putaud, J. P.: Aerosol activation in marine stratocumulus clouds: 2. Kohler and parcel theory closure studies, J. Geophys. Res., 108, 8629, doi:10.1029/2002JD002692, 2003.

Snider, J. R., Wex, H., Rose, D., Kristensson, A., Stratmann, F., Hennig, T., Henning, S., Kiselev, A., Bilde, M., Burkhart, M., Dusek, U., Frank, G. P., Kiendler-Scharr, A., Mentel, T. F., Petters, M. D., and Pöschl, U.: Intercomparison of cloud condensation nuclei and hygroscopic fraction measurements: Coated soot particles investigated during the LACIS Experiment in November (LExNo), J. Geophys. Res., 115, D11205, doi:10.1029/2009JD012618, 2010.

Sorjamaa, R. and Laaksonen, A.: The effect of $\mathrm{H} 2 \mathrm{O}$ adsorption on cloud drop activation of insoluble particles: a theoretical framework, Atmos. Chem. Phys., 7, 6175-6180, doi:10.5194/acp-76175-2007, 2007.

Stephens, M., Turner, N., and Sandberg, J.: Particle identification by laser-induced incandescence in a solid-state laser cavity, Appl. Optics, 42, 3726-3736, doi:10.1364/AO.42.003726, 2003.

Subramanian, R., Kok, G. L., Baumgardner, D., Clarke, A., Shinozuka, Y., Campos, T. L., Heizer, C. G., Stephens, B. B., de Foy, B., Voss, P. B., and Zaveri, R. A.: Black carbon over Mexico: the effect of atmospheric transport on mixing state, mass absorption cross-section, and $\mathrm{BC} / \mathrm{CO}$ ratios, Atmos. Chem. Phys., 10, 219-237, doi:10.5194/acp-10-219-2010, 2010. 
Weingartner, E., Burtscher, H., and Baltensperger, U.: Hygroscopic properties of carbon and diesel soot particles, Atmos. Environ., 31, 2311-2327, 1997.

Wyslouzil, B. E., Carleton, K. I., Sonnenfroh, D. M., Rawlins, W. T., and Arnold, S.: Observation of hydration of single modified carbon aerosols, Geophys. Res. Lett., 21, 2107-2110, 1994.

Zelenyuk, A., Imre, D., Han, J.-H., Oatis, S.: Simultaneous measurements of individual ambient particle size, composition, effective density, and hygroscopicity, Anal. Chem., 80, 14011407, 2008.
Zhang, Q., Alfarra, M. R., Worsnop, D. R., Allan, J. D., Coe, H., Canagaratna, M. R., and Jimenez, J. L.: Deconvolution and quantification of hydrocarbon-like and oxygenated organic aerosols based on aerosol mass spectrometery, Environ. Sci. Technol., 39, 4938-4952, 2005.

Zhang, R. Y., Khalizov, A. F., Pagels, J., Zhang, D., Xue, H., and McMurry, P. H.: Variability in morphology, hygroscopicity, and optical properties of soot aerosols during atmospheric processing, P. Natl. Acad. Sci. USA, 105, 10291-10296, doi:10.1073/pnas.0804860105, 2008. 